\title{
The Role of Accounting Information in Financial Performance Measurements from External User's Viewpoint ${ }^{\#}$
}

\author{
Zbyněk HALÍ $\check{R}^{*}$
}

\section{Introduction}

Ensuring a satisfactory performance level is one of the fundamental prerequisites for the successful development of each company. Securing abundance of high quality information, which reflect the level of business performance and help all involved bodies to understand in what direction and why the performance is developed, as well as the possibility of controlling the way they should develop, requires the existence of quality and complex information system and management control system. Under the terms of such a corporate information system, particularly in matters relating to financial performance, an accounting subsystem plays an important role.

Business performance ${ }^{1}$ can be generally defined as the characteristic, which assesses whether the business process helps to achieve business goals. If so, this characteristic should also measure the extent it occurs and what factors contribute to it.

\# The article is processed as an output of a research project The Role of Accounting Information in Financial Performance Measurements registered by the Internal Grant Agency (University of Economics, Prague) under the registration number F1/21/2010 and research plan Development of Accounting and Financial Theory and its Application in Practice from Interdisciplinary Point of View under the registration number MSM 6138439903.

Ing. Zbyněk Halîr - Ph.D. student; Management Accounting Department, Faculty of Finance and Accounting, University of Economics, Prague, W. Churchill Sq. 4, 13067 Prague, Czech Republic; <zbynek.halir@ vse.cz>.

1 Further in the article the issue is narrowed down to measuring and reporting financial performance, which is based on the traditional financial indicators, and which is a hierarchically subordinated item of a complex business performance. Only such a complex performance reflects how the firm leads in a competitive environment and what its growth prospect is like. 
Measuring the performance of this scale is "the process of assessing the proficiency with which a reporting entity succeeds, by the economic acquisition of resources and their efficient and effective deployment, in achieving its objectives". (See CIMA, 1982) High-quality and sophisticated performance measurement system is one of the fundamental prerequisites for the successful business process management. While managing performance the managers strive to influence the economic subjects' development by a rational way - so that they would be able to fulfill the aims they have been founded for. (See Král, 2007)

Financial performance, which is based on traditional financial indicators, is a hierarchically subordinated item of complex evaluation of business performance. It is just one - albeit important - part of the performance.

Every company chooses tools that enable it to achieve the required performance and the criteria that enable it to measure the level of performance achieved. In this regard, the accounting system of a company demonstrates its power, because it is an essential and indispensable source of data for determining the level of financial performance criteria across the whole company.

Whatever activity people are engaged in, they always consider what has to be sacrificed on one hand and what does the activity bring them on the other hand. By mutual comparison of sacrifices and benefits the individual comes to the conclusion on what level of performance he or she has acted.

Such a general view can also be applied to business activity. The essence of business process is always the transformation of inputs to outputs. Inputs that were incurred in business process correspond to sacrifices that were mentioned above and outputs, which are gained thanks to the business process, then correspond to benefits that were mentioned above. In order to reach the desired level of financial performance, it is necessary that the value of total output exceeds the value of total input. The main motive of business is a general appreciation of inputs by gaining a higher output value. This principle is explained in Figure 1. 
Fig. 1: Transformation Process

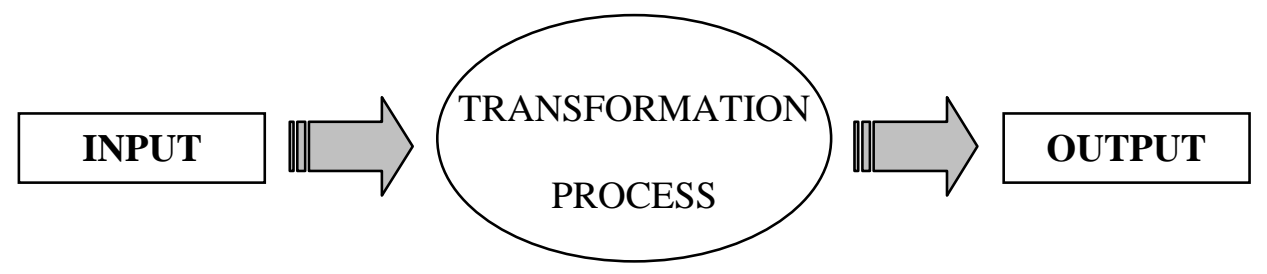

SACRIFICE

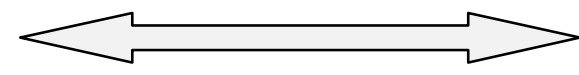

BENEFIT

Source: inspired by Fibírová - Šojlaková - Wagner (2005)

From the relationship between costs incurred and economic benefits gained some important criteria for the rational development of the business process can be derived. The most important of these are measurements of economy, efficiency and effectiveness. Economy is rationality in the use of economic resources. The aim is to achieve desired outcomes at minimum cost. The effectiveness balances incurred costs against achieved economic benefits. This disparity is usually quantified by profit. Finally, efficiency is the ratio of effectiveness (i.e. profit) related to the total of economic resources employed.

This paper is a partial output of the project, which deals with the role of financial and management accounting in performance management. Although the performance measurement issue is pretty diverse and greatly extensive, this paper focuses primarily on the viewpoint of external users of financial accounting, who can measure financial performance. The requirements of company's management (i.e. internal users of management accounting) and tax authorities and other users who formulate their requirements regarding content and structure of tax accounting remain out of the interest of the paper. The paper will be soon followed by another output, which will focus on demands of users of managerial accounting.

Since this paper focuses exclusively on financial performance of the enterprise from the perspective of external users of financial accounting information, the main methodological approach to designing the paper is based on detailed analysis of profit or loss account prepared for external reporting, primarily in the concept of Generally Accepted Accounting Principles of the United States (US GAAP). In many places in the text the 
Halír, Z.: The Role of Accounting Information in Financial Performance Measurements from External User's Viewpoint.

concept of US GAAP is compared to the concept of International Accounting Standards / International Financial Reporting Standards (IAS / IFRS) (2005) and also to the concept of the accounting regulation of the Czech Republic.

The main aims of the paper are to analyze the approach of US GAAP and IAS/IFRS to reporting, measuring and managing the financial performance and to specify the field

- where the inspiration for amendment of Czech accounting legislation, the Czech accounting standards and their interpretations can be found;

- where the inspiration for solving partial inconsistencies between IAS / IFRS and US GAAP can be found and where recommendations for continuing of harmonization process of both accounting systems in the field of measuring and reporting of financial performance can be given.

\section{Content Definitions}

Fulfillment of the stated aims of the paper requires the definition of content of the issues studied.

The terms business performance and financial performance have been defined in the introduction to the paper. At this point I only mention very briefly that the performance is generally understood as the ability of an entity to achieve its objectives, while financial performance is just one of its components, which can be measured and controlled by financial criteria.

As mentioned above, the issue of measuring financial performance is inextricably linked to the accounting system of an entity. Accounting is a scientific discipline, which - although evolving for centuries - has not been clearly defined. ${ }^{2}$ This is caused by several different reasons.

The first one of these reasons is the fact that the concept of accounting is used in several meanings. It is usually used in following meanings:

2 In my opinion, the fact that the term "accounting" has not been exactly defined up to the present day is not a deficiency. Accounting is primarily a practical discipline; not the content definition but its methods and procedures are crucial. 
- theoretical scientific discipline that deals with displaying the economic reality of a company and its surroundings, according to clearly defined rules;

- practically performed activity, involving the description of economic reality; in other words bookkeeping ${ }^{3}$.

The second reason (and probably the most important one in the context of the paper) is the fact that the concept of accounting is perceived in different ways in the environment of continental Europe and Anglo-Saxon world. I would like to draw attention to the paradoxical perception of continental and Anglo-Saxon view of the wording of accounting regulation and recommendations. In continental Europe, the accounting is perceived as a relatively clearly defined system, based on specific rules and established practices. Contrary to so-called continental perception, in Anglo-Saxon world the accounting is rather perceived as a communication tool and its form is usually left to the deliberation of the participating entities. In its final form the accounting system should help the entities to make the decisions as qualified as possible and to assess all the relevant facts. The paradox of the whole matter is that clearly defined accounting systems of continental Europe are often governed by legislation on hardly dozens of pages, while freely defined accounting systems of the Anglo-Saxon environment are described on thousands of pages of text. ${ }^{4}$

The third reason for the ambiguity mentioned above is the differentiation between accounting system designed for external users (i.e. interest groups outside the company) and accounting system for internal use (i.e. accounting system as a tool of information support for the management of company).

3 The Czech language does not distinguish between "accounting" and "bookkeeping". It has only one common term for both meanings.

4 The basic difference between both areas is a different way of development related to the legal framework, as well as to the social and cultural habits. It is true that in continental Europe, companies are often tied by the diction of accounting legislation, while in Anglo-Saxon areas more choice is generally left. In real world, if the company wants to survive - and even thrive - it is necessary to adopt these recommendations as rules. From a certain perspective, it is possible to say that there is even more pressure exerted on the true and fair view of accounting information in the Anglo-Saxon world. However, it is enforced in different ways, particularly by a developed legal system and a number of precedents. 
Halîr, Z.: The Role of Accounting Information in Financial Performance Measurements from External User's Viewpoint.

If we find conjunctions of all different approaches, we find that there is a common effort to design the accounting system, which can legitimately be considered as "the information system based on rigorous methodological principles and generally accepted principles, that aim to provide users with a true and fair view of reality and conclusive, complete, reliable, comparable and understandable information". (See Kovanicová, 1993)

\section{US GAAP as a Source of Inspiration}

In simple terms, the US GAAP is the system under which the financial statements are prepared and then submitted to individual investors and other external users. What should be emphasized is that the legislative compliance of the system is not required ${ }^{5}$, while in the environment of continental Europe - where we live - the accounting regulation is given by law.

Now we have pointed out one of the major differences between the worldwide accepted accounting principles (we can refer to IAS / IFRS as well as to US GAAP) and Czech accounting legislation. It is the origin of the documents regulating the accounting issues. While the IFRS and US GAAP are created by professional organizations, which members are experts and specialists in accounting, in the Czech Republic the accounting area is governed by the law and the other related regulations. The law is shaped by a political and usually not professionally qualified force. Accounting is a pretty complex and sophisticated matter, which requires people who have studied it carefully and for a long time. I am afraid that the politicians hardly count among these people. Although, Czech Accounting Act (in accordance with US GAAP and IAS / IFRS) requires true and fair view of reality, it is - unfortunately - under strong pressure from tax laws, which pursue completely different goals. Following the US GAAP model would be a beneficial step. In the United States the financial accounting is separated from the tax accounting and that is way US GAAP - which regulate the financial accounting - do not deal with computing and payment of taxes.

5 Despite this theoretical latitude, however, if a company wants to survive and prosper it absolutely needs sources of credit. Thereafter, it has to respect these rules and comply with them. Compliance with these rules is necessary, because the company needs to be able to demonstrate the accuracy and fidelity of the information presented and reported and to be able to succeed in a potential lawsuit. 
Another consequence of the fact that the Czech accounting is governed by legal standards is the occasional victory of legal form over substantive content. Both US GAAP and IAS / IFRS consider the economic substance of displayed event as crucial. Even though this requirement is formally codified by the Accounting Act of the Czech Republic, the fact of the matter is different. Many examples can be found. One for all, we can mention for example the accounting for lease contracts, the definition of "revenue" and "expense" or recognition and reporting of extraordinary items. All of these issues will be discussed later in the paper.

To remain unbiased, it is necessary to mention also the dark side of US GAAP. They are rather difficult to grasp. The difficulty lies in its nature and structure. US GAAP have undergone continuous development since the early 1930s, when it began to emerge as a consequence of the stock market crash of 1929 and subsequent economic crisis. It was because of the widespread perception that an absence of uniform and stringent financial reporting requirements had contributed to the rampant stock market speculation that culminated with the collapse of the stock market and that destroyed the entire economy of the United States. ${ }^{6}$ In the course of time the system has gradually been updated and amended. ${ }^{7}$ The precedents from previous lawsuits have also brought many changes in the understanding of the regulation. Such a development has led to the spread between standards and to a number of duplications or inconsistencies in the text of standards. The whole problem is also intensified by the fact that the authors of US GAAP are many independent institutions. ${ }^{8}$ The IAS / IFRS began to emerge in the 1970s, moreover very slowly at the beginning. Only since the late 1980s dozens of accounting standards based on a common conceptual framework have emerged in about 20 years. Furthermore, the IAS / IFRS have been developed by the only one

6 Although the history of US GAAP is a very interesting matter, its detailed description would be beyond this paper.

7 An example that demonstrates this process is a document ARB 43, which deals with inventories. This bulletin was created in the 1950s and has been valid until today. Naturally, it had to go through a number of modifications and amendments over time, since when it was issued, it could hardly reflect the conception of the inventories of these days. Nowadays, some companies have significant part of their inventories in the form of intangible products, but even today the ARB 43 defines inventory as tangible personal property.

8 Another unpleasant consequence is the fact that there is not a publication, which would be comprehensive and complete release of all concepts, standards and other documents which form the US GAAP. IAS / IFRS do have such a publication. 
institution (IASB, International Accounting Standards Board) which is the author of all documents. The result of this intensive and timecondensed development is strong linking of standards with the conceptual framework, as well as standards with each other. Standards contain mutual references and do not contain duplicate wording. The whole system seems to be more consistent. If there was created a new, conceptually formed accounting regulations in the Czech Republic, it would be an intense and rapid process. Therefore, there is no reason to fear of the inconsistencies mentioned above.

It would not be correct, if the above-mentioned difficulties with the grasp of US GAAP seemed to be too negative. Let us mention also of one of their major advantages. The number and the scope of documents comprising US GAAP provide enough space for publishing rich illustrative examples and technical discussions with the arguments both for the solution adopted and also against it. On the contrary, the IAS / IFRS do not offer many illustrations and the solutions adopted are justified as briefly as possible. A proper example is the approach to the extraordinary items. IAS $1^{9}$ explicitly says that no items may be reported as extraordinary, but it does not offer a satisfactory explanation of this decision. This issue will be discussed later in this paper.

\section{Non-conceptual passing of Czech accounting legislation}

Differences in the concept of financial performance under US GAAP, IAS / IFRS and Czech accounting legislation and in it's measuring, consist in conception of these accounting systems. IAS / IFRS have the Conceptual Framework, which is the ideological basis of accounting standards. US GAAP consider the Statements of Financial Accounting Concepts (SFAC) (FASB, 2010) as their "conceptual framework". It consists of five documents, namely SFAC $1^{10}$, SFAC $4^{11}$, SFAC $5^{12}$, SFAC $6^{13}$ and SFAC $7^{14}$. This paper focuses primarily on business organizations, so the interest is put on concepts 1,5 and 6 . They deal with:

\footnotetext{
9 Presentation of Financial Statements

${ }^{10}$ Objectives of Financial Reporting by Business Enterprises

${ }^{11}$ Objectives of Financial Reporting by Nonbusiness Organizations

${ }_{12}$ Recognition and Measurement in Financial Statements of Business Enterprises

13 Elements of Financial Statements by Business Enterprises

${ }^{14}$ Using Cash Flow Information and Present Value in Accounting Measurements
} 
- objectives of financial reporting;

- qualitative characteristics of accounting information;

- definitions of elements of financial statements;

- recognition and measurement concepts.

The Czech accounting treatment does not know a conceptual framework. Likewise, it does not know anything similar what would do its job. The absence of a conceptual framework that represents the whole ideological basis of accounting regulations is very significant handicap for understanding the role of accounting information in the entire economy and for the development of accounting systems in general. Conceptual frameworks of IAS / IFRS and US GAAP do not only help to resolve specific accounting cases, but primarily to help authors of the set of standards in creating new documents. Conceptual framework has also important educational role for external users of accounting information. In this matter a user of Czech accounting statements may feel somewhat neglected. It is possible to say that a high-quality conceptual framework is an important thing for prevention of creation of non-conceptual standards.

Now let's look briefly at consequences of lack of a conceptual framework. In connection with measuring and reporting of financial performance, one of the most important manifestations of an absence of a conceptual framework are unclear and economically incorrect definitions of expense and revenue in the Czech accounting legislation. It leads to the fact that expenses and revenues, which the Czech accounting legislation works with, do not correspond to the categories of expenses and revenues that are defined in the world's developed accounting systems (IAS / IFRS, as well as US GAAP). There exist numerous problems that are similar to this one. If fundamental principles are missing, it is - unfortunately necessarily reflected in the form of national accounting legislation. In this area, I can see a considerable scope for improving the overall concept of Czech accounting regulation. 


\section{Key Elements of Financial Performance}

Basic elements of financial statements are defined primarily in SFAC 6, which replaced the earlier SFAC 3. Information about earnings ${ }^{15}$ and all its components are integrated into a complex indicator of financial performance, which is called Comprehensive Income. The Comprehensive income (item B.1 in Figure 2) shows the total change in the company's capital during the accounting period. It is a result of all events and transactions affecting the amount of equity (item B), except for all changes in equity from direct transfers between the company and its owners (item B.2) - i.e. investments by owners in the enterprise (item B.2.a) and distributions by the enterprise to owners (item B.2.b). We can briefly say that the comprehensive income corresponds to all changes in equity for the period, excluding those generated by direct transactions between the company itself and the owners of the company.

Formerly, IAS / IFRS did not know the term Comprehensive Income, but in fact they demanded its showing by the requirement of drawing up the statement of changes in equity. In late 2007, IASB issued revised IAS 1 (effective in 2009), which introduced as a major change the replacement of profit and loss statement with the statement of comprehensive income. The revision brings IAS 1 largely into line with the US standard SFAS $130^{16}$. This synthetic indicator (comprehensive income) includes all non-owner changes in equity. The revision also requires presenting the information about comprehensive income and all its components within a set of basic financial statements.

Comprehensive income (i.e. a profit or loss for the period) is defined in relation to events, which have led to the emergence and recognition of one of the following elements during the period:

15 Earnings is a measure of what a company actually earned during an accounting period. The difference between net income and earnings is that earnings does not include the cumulative effect of certain accounting adjustments of earlier periods that are recognized in the current period (these changes are not a real profit, but rather consequence of a change in accounting policy or rule). The terms "profit" and "earnings" are very close to each other. SFAC 5 even in the paragraph 33 notes that the FASB anticipates that net income, profit, net loss, and other equivalent terms will continue to be used in financial statements as names for earnings.

16 Reporting Comprehensive Income 
- revenue - item B.1.a in Figure 2;

- expense - item B.1.c in Figure 2;

- gain - item B.1.b in Figure 2;

- loss - item B.1.d in Figure 2.

SFAC 6 also separates elements of business performance, which come from the entity's ongoing major or central operations (core business) from those which come from peripheral or incidental transactions.

Fig. 2: All transactions and other events and circumstances

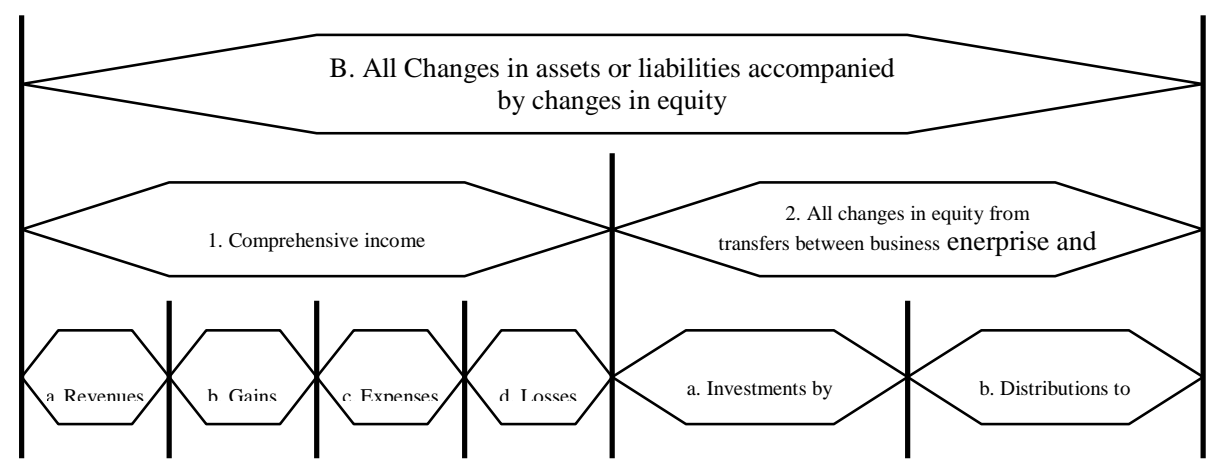

Source: inspired by IASB: SFAC 6, 1985

Elements connected with ordinary business activities (ongoing major or central operations) are defined in paragraphs 78 to 81 of SFAC 6 . These are the following:

- revenues are inflows or other enhancements of assets of an entity or settlements of its liabilities (or a combination of both) from delivering or producing goods, rendering services, or other activities that constitute the entity's ongoing major or central operations;

- expenses are outflows or other using up of assets or incurrences of liabilities (or a combination of both) from delivering or producing goods, rendering services, or carrying out other activities that constitute the entity's ongoing major or central operations.

Now, I would like to discuss briefly completely different definitions of "revenue" and "expense" in US GAAP (and all global sets of accounting standards) and definitions of "revenue" and "expense" in the Czech accounting legislation. In US GAAP the term "revenue" corresponds to the term "sales" in the Czech accounting legislation (in 
particular Decree of the government No. 500/1992). The concept of "revenue", as we know it from the Czech accounting legislation has no parallel in the whole wide world. As in the case of revenue in the Czech accounting legislation, the term "expense" is also defined problematically there and does not match the category of "expense" in US GAAP. These discrepancies arise mainly from different accounts of variation of stocks and capitalization of own products. The substantive and time inconsistencies between recognized revenues from operating activities and expenses from operating activities classified by nature are resolved by the change of revenues when using the variation of stock account in the Czech Republic. This solution is methodologically questionable. ${ }^{17}$ Proper is the opposite solution. The level of revenues recognized is exogenous and corresponding expenses are adjusted. Reflecting this fact and harmonizing the Czech accounting terminology with the overwhelming part of the world can only be beneficial step.

Paragraphs 82 to 86 of SFAC 6 define the elements of financial performance, which are connected with peripheral or incidental transactions. These are the following:

- gains are increases in equity (net assets) from peripheral or incidental transactions of an entity and from all other transactions and other events and circumstances affecting the entity except those that result from revenues or investments by owners;

- losses are decreases in equity (net assets) from peripheral or incidental transactions of an entity and from all other transactions and other events and circumstances affecting the entity except those that result from expenses or distributions to owners.

US GAAP consider the classification of elements based on their connection with the ongoing major activities (revenues, expenses) or with secondary activities and peripheral transactions and events (gains, losses) as crucial and require their separate recognition. IAS / IFRS mention gains and losses, but only within the broader categories of income and expenses. In IAS / IFRS the terms expenses and income are broad enough to include losses as well as normal categories of expenses and gains as well as revenues. It differs from the corresponding US GAAP standard,

17 Incorrect definition and understanding of revenues is reflected in the financial analysis. As a result of incorrectly recognized levels of revenues and expenses all the profitability ratios and asset turnover ratios are distorted. 
which deems gains and losses to be separate and distinct elements to be accounted for.

The Czech accounting legislation differs from this approach in much more significant way. Czech profit and loss account does not know more than one class of expenses and revenues. These two elements are not broken down depending on their relationship to ongoing major activities or peripheral transactions. Both of these elements (covering all the elements of revenues, expenses, gains and losses) are shown in the Czech income statement, but they are not paid closer attention. Therefore, they are not reported separately, as in the case of income statement prepared in conformity with US GAAP.

The US GAAP (and largely the whole world) respect the principle that expenses and revenues connected with operating activities are always shown in the income statement itself. The situation of gains and losses is more interesting and complicated. In fact, gains and losses can be divided into two parts. The first one consists of gains and losses that are shown in the income statement and the second one consists of those gains and losses that have a direct impact on equity. Issue around relationships between elements of the income statement is quite interesting and from a European perspective a little complicated.

In paragraphs 82 and 83 of SFAC 6 , the relationship of gains and losses to the peripheral activities or incidental transactions is highlighted. However, paragraph 86 states that gains and losses can be classified as operating ${ }^{18}$ or non-operating depending on their relationship to the ongoing major activity or peripheral transactions. At first glance, it appears that the wording of paragraphs 82,83 and 86 come into mutual conflict, but in fact they do not. In the environment of continental Europe, we are accustomed to exhaustive definitions of the items that fall into different sets, which also have clearly defined and established end points. In the approach of US GAAP accounting standards are rather a guide and a set of recommendations that help an entity to show and report all events and transactions in a proper way. A number of terms are relatively loosely

${ }^{18}$ US GAAP define the operating activity as the core business of the enterprise, i.e. the activity for which it was founded. Performing of such an activity is main mission of a company. All other secondary and incidental transactions are then defined as nonoperating. 
defined and the boundaries between them are often blurred. ${ }^{19}$ The final decision depends on the particular conditions and circumstances and is left to the discretion of an entity. For better understanding, let me mention an example of an actual company. When considering the write-down of inventories because of fall in value, it is a loss, which is relatively closely related to the core business of the company. It is therefore an operating loss Operating Loss. However, if some random and rare event - for example an earthquake that destroys all the inventories - comes, then the company account for its consequences through non-operating loss.

The significant difference in the reporting of the above mentioned elements of financial statements is the fact that revenues and expenses are usually displayed separately as gross increases and decreases of equity, while gains and losses are usually reported on a net basis.

In addition to the unification of the terms revenues and expenses in the Czech accounting legislation with revenues and expenses in the world's developed financial systems (IAS / IFRS and US GAAP), there is another logical step in the unification process. "Expenses" and "revenues" derived from major business activity have a different character than "expenses" and "revenues" 20 , whose origin lies in the peripheral or incidental transactions. Different nature of the activities mentioned above should be reflected not only by the definitions of the elements of income statement, but also by its rich structure.

\section{Structure of Income Statement}

US GAAP (as well as IAS / IFRS) do not prescribe an obligatory form of income statement. They only require a true and fair view and disclosure of all material facts. They also offer the proper illustrations how to classify the items.

The Czech profit and loss account is standardized by the legislation. Since 2002, the company has been at least allowed to show the additional items, which are to be presented under the section that they are connected

19 The words "... and from all other transactions and other events and circumstances affecting the entity ..." in the definitions of gains and losses leave a considerable scope for the inclusion of additional items, which inclusion is assessed as appropriate and correct by the entity.

${ }^{20}$ They are called "gains" and "losses", but we do not know these terms in the Czech accounting regulation. 
with. The structure of Czech income statement is, unfortunately, negatively influenced by strong linking of the Czech financial accounting to taxes. Naturally, it has an unpleasant impact on the explanatory power of Czech profit and loss account. Some items are affected by taxes so much that the information about financial performance is distorted. Typical examples of such items are lease contracts, changes in accounting policies, changes in accounting estimates or corrections of errors.

Czech accounting legislation structures the income statement into three basic sections, namely:

- profit or loss from operational activities;

- profit or loss from financing activities;

- profit or loss from extraordinary activities.

US GAAP provide a much deeper and more comprehensive picture of financial performance achieved. At the first level of classification they structure the income statement into:

- profit or loss from continuing operations;

- profit or loss from discontinued operations;

- profit or loss from extraordinary items.

At the next level of classification, mainly the result of continuing operations, which is usually the most important of the three above mentioned sections is divided according to the activity it comes from. There are two possibilities:

- major or central activities;

- peripheral or incidental transactions.

Classification of the elements of performance and of types of operations mentioned above is linked to the multilevel structure of the income statement. In Figure 3 is presented a model of statement of comprehensive income, which meets the needs of the above mentioned statements of financial accounting concepts (SFAC) and reflects the relationship of particular items to various business activities. Such a classification, which is in context of financial performance measurements very valuable information, is unfortunately not known in the Czech accounting legislation. The structure of income statement, which is 
Halîr, Z.: The Role of Accounting Information in Financial Performance Measurements from External User's Viewpoint.

presented in Figure 3 may be a good inspiration for the accounting legislation of the Czech Republic.

Fig. 3: Structure of Statement of Comprehensive Income

\section{$\Rightarrow$ EFECTS FROM CONTINUING OPERATIONS}

Sales or Service Revenues

- Cost of Goods Sold

GROSS PROFIT

- Other Operating Expenses (Selling; Administrative)

+ Gains

- Losses

+ Other Revenues

- Other Expenses

\pm Unusual or Infrequent Gains or Losses

- Income Tax Expense Related to Continuing Operations

Income from Continuing Operations

$\Rightarrow$ EFECTS FROM DISCONTINUED OPERATIONS

\pm Income/Loss from Operations of a Discontinued Component

\pm Gain/Loss from Disposal of a Discontinued Operations

Income Tax Expense Related to Continuing Operations

$\Rightarrow$ EFFECTS FROM EXTRAORDINARY ITEMS

\pm Gains or Losses that are both Unusual and Infrequent

CUMULATIVE EFFECT OF CHANGES IN

$\Rightarrow$ ACCOUNTING PRINCIPLE

GAINS AND LOSSES RELATED TO OTHER

$\Rightarrow$ COMPREHENSIVE INCOME

+ Gain

- Losses

COMPREHENSIVE INCOME

Source: inspired by Epstein - Nach - Bragg (2010)

In the following chapters we will discuss the three mentioned blocks of the statement in more detail. 


\section{Income from Continuing Operations}

This section of the income statement deals with displaying activities, which are expected to continue at least in the subsequent period. That is why the information from this section of the income statement is the most proper for the assessment of future potential of the business. In this section, mainly the revenues and expenses from the entity's ongoing major or central operations are reported, but also other revenues and expenses from secondary activities and some gains and losses, which have their origin in peripheral or incidental activities.

Although US GAAP do not impose a specific structure of income statement and do not list items in this statement, the items that the income statement, which is presented to investors, creditors and other external users of accounting information should contain are obvious. They are:

- Sales / Revenues;

- Cost of Goods Sold;

- Gross Profit (Gross Margin);

- Other Operating Expenses;

- Gains and Losses;

- Other Revenues and Other Expenses;

- Unusual or Infrequent Items;

- Income Tax from Continuing Operations;

- Income from Continuing Operations.

In particular, I find interesting the gross profit, which is closely related to the choice of classification of expenses either by nature or by function. IAS/IFRS (and also the EU Fourth Directive) offer two different ways of classifying of operating and other expenses. Both classifications by nature and by function are possible and are considered as equivalent solutions. However, if the company chooses a classification by function, IAS / IFRS require disclosing additional information about structure of expenses by their nature. This option possibility is just one example of the relative freedom that IAS / IFRS let the entity in the presentation of information. IAS / IFRS even leave up to the entity, whether some highly relevant information ${ }^{21}$ will be recognized directly in the income statement or it will only publish it in the notes. Another

${ }^{21}$ For example, we should mention the effect from discontinued operations or the effect from changes in accounting principles. 
Halîr, Z.: The Role of Accounting Information in Financial Performance Measurements from External User's Viewpoint.

example is a series of situations in which IAS / IFRS allow alternative solutions. US GAAP requirements for the income statement are much more detailed, explicit and definite. In my opinion, the US GAAP approach to these issues is more correct, because the alternative solutions and options for presenting leave sufficient room for blurring information about performance of the reporting entity. Another consequence of such freedom is limited comparability of reported financial statements.

Czech accounting legislation is in matter of classification of expenses in accordance with IAS / IFRS. In earlier years only classification by nature was eligible, but since 2003 also alternative classification of expenses by function was allowed. If the company chooses this option, it is also required to present additional information about structure of expenses by their nature in the notes.

To better assess the explanatory power of the two income statements, which are based on classification of expenses by nature and by function, we can imagine a simple example. There are two companies - Company A and Company B. These are two totally comparable firms, which report the income statements for the year ended 31 December. We can see them in Figure 4.

\section{Fig. 4: Income Statements of Companies A and B}

\section{Company A}

Income statement for the year ended

31 December 2009

Sales or Service Revenues $\quad 100$

Cost of Good Sold

Gross Profit

Administrative Expenses

Income

20

\section{Company B}

Income statement for the year ended

31 December 2009

Sales or Service Revenues $\quad 100$

\begin{tabular}{ll} 
Cost of Good Sold & 20 \\
\hline Gross Profit & $\mathbf{8 0}$
\end{tabular}

\begin{tabular}{ll} 
Administrative Expenses & 70 \\
\hline Income & $\mathbf{1 0}$
\end{tabular}

Source: inspired by Mládek, R.: World Accounting. 2002; my own elaboration

We can also see that both companies reported the same level of income for the period. If the companies prepared income statements based on classification of expenses by nature, they would appear to reach exactly the same level of performance. However, both companies reported the income statement based on classification of expenses by function, and therefore we can also see completely different structure of their expenses. 
What more, we can see totally different level of performance of both companies.

Now, the question is which of the companies seems to be better investment for potential shareholders. At first glance, this is Company B. It is able to operate and produce much more efficiently, and thus it reaches much higher gross margins than Company A. On the other hand, Company B incurs disproportionately higher share of administrative expenses (note that both companies are totally comparable), which indicates that current management of the Company B may not act fully consistent with the interests of the shareholders. There is probably huge room for reducing the administrative costs.

From the example it is obvious that the great advantage of the income statement based on classification of expenses by function is its informative power. But we should not overlook the fact that this advantage can also be perceived as the disadvantage in the aggressive competitive environment that prevails in most markets these days. Companies do have a natural tendency to hide the secrets of business success. However, if we keep the perspective of external users of financial accounting statements, we have to appraise the income statement based on classification of expenses by function as much more valuable data source.

\section{Income from Discontinued Operations}

Reporting the information about discontinued operations is regulated by SFAS $144^{22}$ These are operations with component of the entity that is disposed of by sale, disposed of by abandonment, exchanged for similar productive asset or distributed to owners in a spinoff.

To recognize the discontinued operations the two important dates that are indicated in the Figure 5 are important:

- measurement date, which is the date when the management of the company make a decision to dispose a component of an entity; the component is then named as an asset to be disposed of by sale;

- disposal date, which indicates the date of termination of the process of disposal.

\footnotetext{
22 Accounting for the Impairment or Disposal of Long-Lived Assets
} 


\section{Fig. 5: Timeline of the Termination of Operations}

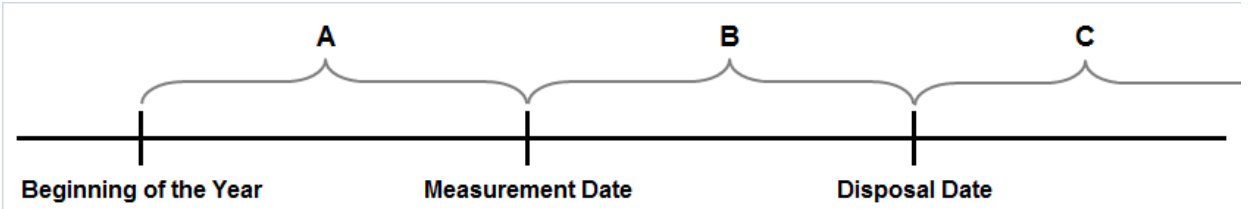

Source: my own elaboration

According to US GAAP, result from discontinued operations is recognized separately from the result from continuing operations and is reported in a separate part of the income statement. It should be displayed before extraordinary items and cumulative effect of changes in accounting principles. Once it was decided to discontinue the operation, it is unacceptable that the result had been reported in the section of continuing operations. This requirement is in terms of explanatory value of the financial statements absolutely logical. Although the company reported excellent results, it may be highly misleading information to potential investors, if the company had reduced its production. Until the completion of the disposal process the result of operation is reported in special section of the income statement, which is determined for that purpose. Then, a clear separation of such effects on the income of continued operations is ensured.

This section of the income statement is further divided into two separate subsections depending on the measurement date of the operation. The subsections are:

- profit / loss from operations - this item is presented, if the decision to close down the component of the company was made after the beginning of the fiscal year for which financial statements are compiled; this period corresponds to the time interval A in Figure 5, i.e. time elapsed since the beginning of the year to the measurement date;

- gain / loss on disposal - this component, which is always presented in the case of discontinuing of a component (without the reference to the measurement date), consists of two sub-sections:

- profit / loss from operations conducted between the date of measurement and the disposal date; this period corresponds to the time interval B in Figure 5; 
- gain / loss from the disposal of the component of the company itself.

The income statement prepared in accordance with Czech accounting legislation has not a separate section for discontinued operations. Socalled "transfer accounts" provide at least partial solution. They allow the reporting entity to transfer revenues and expenses associated with the discontinued operations to another (non-operational) section of the income statement. However, the question is to which section. Probably the only option is to report the effects from the discontinued operations in the notes. Nevertheless, both revenues and expenses are transferred separately and the aggregate result from discontinued operations is not recognized.

\section{Effects from Extraordinary Items}

In general, extraordinary items are acts of God or governments such as natural disasters, wars, nationalization, etc. These items are both of an unusual nature and infrequent in its occurrence. Extraordinary items should be segregated from the results of ordinary operations and be shown net of taxes in a separate section of the income statement, following discontinued operations. Standard APB 30 deals with this matter in more detail. It offers examples of extraordinary items on one hand and items that should not be classified as extraordinary under any circumstances on the other hand. Other specific standards ${ }^{23}$ extend the list with examples of items that are considered as extraordinary even if they do not meet both criterion of unusual nature and infrequent occurrence.

In the matter of extraordinary items IAS / IFRS differ significantly from US GAAP. While US GAAP define the extraordinary items quite clearly and require separate recognition of effects arising from them, IAS / IFRS as present amended do not know the extraordinary items at all. In earlier times extraordinary items used to be published separately from all other items. However, IAS 1 in paragraph 85 expressly prohibits recognition of any item in the income statement or in the notes as extraordinary. ${ }^{24}$ In my opinion, this weakens the explanatory power of financial statements prepared under IAS / IFRS in comparison to financial

${ }^{23}$ For example the effect from premature settlement of liabilities (discussed in SFAS 4).

${ }^{24}$ Even the last amendment to IAS 1, which is effective since early 2009 does not change anything. 
statements prepared in accordance with US GAAP. The transactions, which reflect the effects of phenomena such as natural disasters are truly extraordinary nature and the assumption that they will not be repeated can be considered as legitimate. Not showing such items as extraordinary may then lead to biased judgment of external users of financial statements.

Previously, IAS 8 in paragraph 6 defined extraordinary items as income or expense resulting from events or transactions that are clearly distinct from the ordinary activities of the entity, and therefore are not expected to occur frequently or regularly. Consequently, the IASB decided to remove the extraordinary items from IAS 8 and IAS 1 . As the only justification for this step, the IASB says that all transactions (even those, which are understood as extraordinary) result from normal business risks and the judgment of their impact is often subjective. Numerous factors in accounting, however, are considered subjectively. I do not consider the argument mentioned above satisfactory enough to justify the abolition of the part of the income statement, which provides investors much needed information.

Effects from extraordinary events, generally tend to have very substantial implications for the management of entity, which must proceed in accordance with paragraph 86 of IAS 1, which says: When the item of income or expense is material, it must be disclosed separately. The result is the obligation of an entity to reporting such effects, which cannot be done without a subjective assessment of relevant events. Finally, the only difference is that the investor has to look for this information (usually in the notes), instead of seeing properly structured income statement, which has a special section to show such effects.

Regarding the Czech accounting legislation, the situation is more complicated. The concept of extraordinary items is known in the Czech accounting legislation, however, the content is completely different from diction of US GAAP. In the Czech income statement are not only unusual and infrequently occurring events marked as extraordinary items, but also items such as effect from changes in accounting policies, changes in estimates, errors etc. These items (changes in accounting principles, methods, etc.) should be reported in a separate section of the income statement according to US GAAP. In contrast, CAS $019^{25}$ says in this context that change in accounting principle expenses (as well as many

${ }^{25}$ Czech Accounting Standard for Businesses No. 019 - Expenses and Revenues 
other items of expenses) are debited to an account of account class $58-$ Extraordinary expenses. ${ }^{26}$ The wording "unusual and infrequently occurring items" is not known in the Czech accounting legislation and therefore is not required to be reported separately.

\section{Conclusion}

Turbulent and aggressive competitive environment of today's world increasingly forces organizations to understand business performance rather as a future potential ability to succeed in the marketplace than as plain view on the present or the past. One of major components of this broadly understood business performance is financial performance. In today's business environment an increasing emphasis is therefore placed on finding high-quality information about financial performance. A highquality information system becomes a necessity. Accounting subsystem includes financial information, which creates conditions for effective management of financial performance. Such information helps all interested parties to understand the direction and causes of company's development.

Analysis of two most developed world's financial systems - IAS / IFRS and US GAAP, has become in line with the expectations a rich source of inspiration for improvement of the Czech accounting legislation, the Czech accounting standards and their interpretations. The lack of conceptual framework is a crucial problem of Czech accounting regulation. This fact leads to many content inconsistencies or even worse to economic errors, which are discussed in this paper.

- The Czech financial regulation lacks definitions of basic concepts, required qualitative characteristics of accounting information, recognition and measurement concepts (assumptions, principles, constraints) or even objective and purpose of preparing financial statements itself.

- Czech accounting is strongly linked to demands for reporting and payment of tax obligations. The strict separation of tax accounting and financial accounting would certainly create the environment, where the economic substance of financial transactions would prevail over their form. Particular

${ }^{26}$ There is explicitly defined chart of accounts in the Czech Republic and certain items are numbered. 
Halír, Z.: The Role of Accounting Information in Financial Performance Measurements from External User's Viewpoint.

manifestations of problem issues are concept of leasing contracts, correction of accounting errors, changes in accounting principles, etc.

- The definitions of "revenues" and "expenses" in the Czech accounting legislation are questionable, because of the absence of definitions of the fundamental concepts. These terms are removed from "revenues" and "expenses" as understood in all advanced accounting systems of the world. It results from a different approach to accounts of changes in self manufactured inventory and capitalization. ${ }^{27}$

- In the Czech accounting the content of extraordinary items is highly controversial. They often do not have an extraordinary character.

Another drawback of the Czech accounting regulations as compared to US GAAP or IFRS is too plain structure of information regarding financial performance. It causes in particular:

- lack of separation the ongoing major activity from the other operations, i.e. either incidental or peripheral activities and operations, which do not create the potential for future performance enhancement; the most problematic section of the Czech income statement is operational section, which contain a mixture of major and secondary activities (which are not clearly separated);

- Czech accounting regulation almost does not deal with discontinued operations, despite the fact that under US GAAP and IFRS is paid much attention to them; effects from such activities do not constitute a future potential and it is good to see them apart from other effects;

- US GAAP or IFRS are not law and are therefore applied on the basis of discretion of reporting entity and not as formal and procedural laws. The Czech Accounting Act is law. US GAAP or IFRS do not impose any strict accounting procedures, specific reporting format, the chart of accounts or categories of assets.

US GAAP (as well as IFRS) provide inspiration for a more detailed breakdown of the income statement, which also can be done in multiple

\footnotetext{
${ }^{27}$ Numbers 61 and 62 in Czech chart of accounts.
} 
perspectives simultaneously. This multidimensional income statement would be considered by users of its information as much more valuable document, which would provide a fuller and truer picture of achieved financial performance of the company.

The paper also points out specific areas where the inconsistency between the reporting of information about financial performance under IFRS and US GAAP can be found. These areas should become a subject of interest in further process of convergence and harmonization of these two accounting systems.

From 1 January 2009 there is a significant convergence in reporting of financial performance information. Companies reporting under IFRS since that date can no longer "hide" part of their income directly into the equity. The latest amendment to IAS 1 brought a new concept of income - so-called comprehensive income. However, a small difference between US GAAP and IFRS still exists. IFRS summarize the terms "expenses" and "losses" into a broader "expenses" and the terms "revenues" and "gains" into a broader "income". By contrast, US GAAP have four completely separate categories of "revenues", "expenses", "gains" and "losses" and clearly require strict separation of operations related to the major business activities from those related to all other activities.

Much more important difference between US GAAP and IFRS is the approach to extraordinary items. IAS 1 expressly prohibits declaring any item as extraordinary (and even the last amendment, which is effective since 2009 has not changed anything). US GAAP define the extraordinary items quite clearly and require separate recognition of effects arising from them. In my opinion, the US GAAP approach is correct, because the separation of information, which is for assessing future performance potential the least valuable, is correct and useful.

The last notable difference, which the paper deals with, is the method of classification of expenses. IFRS allow a choice in this matter. The entity can classify expenses either on the basis of their nature or on the basis of their function. US GAAP clearly require a cost analysis by function. It is the only option. I perceive the US GAAP approach is correct, because it does not allow the entity to hide the information about gross profit (gross margin). Potential investors would be quite rightly very interested in this information. 
Halîr, Z.: The Role of Accounting Information in Financial Performance Measurements from External User's Viewpoint.

\section{References}

[1] CIMA (2002): Management Accounting - Official Terminology. London, The Chartered Institute of Management Accountants, 1982.

[2] Epstein, B. J. - Jermakowicz, E. K. (2010): Wiley IFRS 2010: Interpretation and Application of International Financial Reporting Standards. Hoboken, Wiley, 2010

[3] Epstein, B. J. - Nach, R. - Bragg, S. M. (2009): Wiley GAAP 2010: Interpretation and Application of Generally Accepted Accounting Principles. Hoboken, Wiley, 2009

[4] Fibírová, J. - Šoljaková, L. - Wagner, J. (2005): Nákladové účetnictví. Manažerské účetnictví I.. (in English: Cost Accounting. Management Accounting I.). Praha, Oeconomica, 2005

[5] FASB (2010): Statements of Financial Accounting Concepts; Statements of Financial Accounting Standards. [On-line], Norwalk, Financial Accounting Standards Board, c2010, [cit. 26 ${ }^{\text {th }}$ October, 2010], 〈www.fasb.org/st>.

[6] IASB (2005): Mezinárodní standardy účetního výkaznictví (IFRS). (in English: International Financial Reporting Standards), Praha, Union of Accountants, 2005

[7] Kovanicová, D. at al. (1993): Finanční účetnictví - světový koncept. (in English: Financial Accounting - World Concept). Praha, Polygon, 2002

[8] Kovanicová, D. (2002): Studie amerických všeobecně uznávaných účetních zásad jako inspiračního zdroje pro tvorbu českých účetních standardì; vybrané problémy. (In English: Study of US GAAP as Source of Inspiration for Czech Accounting Standards; Chosen Issues) In: Rozvoj finanční a účetní teorie a její aplikace v praxi zinterdisciplinárního hlediska.(In English:Development of Accounting and Financial Theory and its Application in Practice from Interdisciplinary Point of View), University of Economics, Prague, Oeconomica, 2002, pp. 312-349.

[9] Král, B. (2007): Řízení výkonnosti a manažerské účetnictví. (In English: Performance Management and Managerial Accounting), In Král, B. et al. (ed.): Koncepce a praxe ř́zení výkonnosti (In English: Theory and Practice of Performance Management), Praha, Oeconomica, 2007, pp. 83-101. 
[10] Král, B. et al. (2002): Manažerské účetnictví. (In English: Management Accounting). Praha, Management Press, 2010

[11]Miller, S. N. - Mládek, R. (1995): Účetnictví versus Accounting. Praha, North Beach Holdings, 1995

[12] Mládek, R. (2002): Světové účetnictví. Praha, Linde, 2002 


\title{
The Role of Accounting Information in Financial Performance Measurements from External User's Viewpoint
}

\author{
Zbyněk HALÍř
}

\begin{abstract}
The paper concerns measuring and reporting of financial performance of an enterprise from external user's point of view. Basic approach of the paper is the analysis of the Income Statement as amended by US GAAP. If it is appropriate wording of US GAAP is enriched by requirement of IAS/IFRS. The paper comes from following premise: Advanced accounting systems of the world could be rich sources of inspiration that would help to improve the Czech accounting legislation, the Czech accounting standards and their interpretations. Where it is appropriate the paper also brings inspiration for solving partial inconsistencies between IAS / IFRS and US GAAP. It gives some recommendations for continuing the harmonization process of both accounting systems in the field of measuring and reporting of financial performance.
\end{abstract}

Key words: Financial Performance; Income Statement; US GAAP; IFRS, Czech Accounting Legislation.

JEL classification: M41. 